\title{
Gold Behavior in Weathering Products of Quartz Vein in Mintom Area South Cameroon (Central Africa)
}

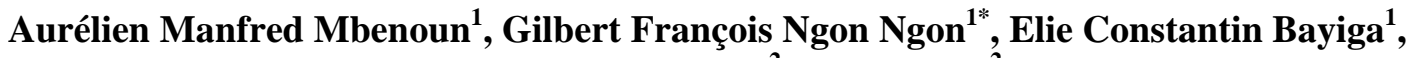 \\ Rose Yongue Fouateu ${ }^{2}$, Paul Bilong ${ }^{2}$ \\ ${ }^{1}$ Department of Earth Science, Faculty of Sciences, University of Douala, Douala, Cameroon \\ ${ }^{2}$ Department of Earth Science, Faculty of Sciences, University of Yaoundé, Yaoundé, Cameroon \\ Email:*gngonngon@yahoo.fr
}

Received August 24, 2013; revised September 26, 2013; accepted October 23, 2013

Copyright (C) 2013 Aurélien Manfred Mbenoun et al. This is an open access article distributed under the Creative Commons Attribution License, which permits unrestricted use, distribution, and reproduction in any medium, provided the original work is properly cited. In accordance of the Creative Commons Attribution License all Copyrights (C) 2013 are reserved for SCIRP and the owner of the intellectual property Aurélien Manfred Mbenoun et al. All Copyright (C) 2013 are guarded by law and by SCIRP as a guardian.

\begin{abstract}
Gold mineralization in Mintom area, south Cameroon was studied in a tropical forest setting using X-ray diffraction, inductively coupled plasma-atomic emission spectrometry (ICP/AES) and inductively coupled plasma-mass spectrometry (ICP/MS) respectively for the mineralogical and chemical data. The mineralization occurs in quartz veins in the archean Ntem complex of the vast Congo Craton in Central Africa. Gold distribution patterns were vertically studied in the different horizons of the weathering profile and in the different grain-size fractions of the materials sampled in the pit on down slope of the interfluve where the mineralization exists. The weathering profile consists of an upper, thin loose sandy-clayey horizon (P6) covered by a light humic horizon, a nodular horizon with lateritic nodules or blocks (P5), a gravel horizon (P4), a thin spotted horizon (P3) and a saprolite (P2) up to $1.4 \mathrm{~m}$ thick. The specific geochemical signature of the bedrock is not recognized in each horizon of the weathering profile. Some groups of elements, e.g., high $\mathrm{SiO}_{2}$ and low $\mathrm{REE}$ characterize quartz vein while $\mathrm{Cr}-\mathrm{Ni}$ characterizes a basic rock like gabbro. The residual gold is concentrated at the base of weathering profile. Its concentration increases from the saprolite up to the gravel horizon and decreases in the surface horizons. However, the evolution of visible Au distribution is not the same for all grain-size fractions: 1) in the finest fraction, the Au content is only regular in spotted and gravel horizons; 2) in the medium size fractions, the $\mathrm{Au}$ is in high content and greatly decreases from saprolite up to the spotted horizon and disappears in the upper horizons; 3) in the coarsest fraction, Au content is found in the saprolite and the maximum Au content of the weathering profile is found in this layer just above the mineralized quartz vein. This observation shows that the Mintom residual gold comes from the quartz vein.
\end{abstract}

Keywords: Geochemical; Gold; Laterites; Mintom; Quartz Veins; Weathering

\section{Introduction}

The supergene mobility of gold in weathering profiles has been well documented in different parts of the world $[1,2]$. The gold-bearing quartz veins and their behavior in weathering profiles of laterites are widely studied $[3,4]$. However, many vast tropical areas are widely covered by a lateritic weathering mantle. In tropical regions, weathering profiles are thick and thus conceal alterations in the bedrock [5]. Also, the lateritic profiles usually consist of three main units, differing in their organization as well as in their lateral continuity: the saprolitic lower unit, the

${ }^{*}$ Corresponding author. glebular/nodular medial unit and the loose upper unit.

In the Ity gold area, Ivory Coast, the Au contents of the laterite profiles are variable $\left(8-25 \mathrm{~g} \cdot \mathrm{t}^{-1}\right)$ and are strongly depleted at the surface (around $1 \mathrm{~g} \cdot \mathrm{t}^{-1}$ ) [6]. They noticed that $\mathrm{Au}$ particles are fine $(<10$ microns) in the saprolite and become larger in the nodular horizon. Moreover, in the lateritic profiles of Surinam and Liberia, $\mathrm{Au}$ is essentially located at the interface of B and C horizons and primary gold dispersion is clearly evident up to the surface [7]. In the laterite of the Boddington gold deposit (Western Australia), the highest Au values occur over mineralized bedrock [8]. However, fine secondary $\mathrm{Au}(<5$ microns) can be observed up to about $500 \mathrm{~m}$ 
from the known deposit and is concentrated in three levels of the profile, in relation to the previous water table $[1,2]$. In the laterite of the Dondo Mobi gold deposit (district of Eteke, south Gabon), the evolution of Au distribution is not the same for all grain-size fractions: $\mathrm{Au}$ is regularly distributed in the weathering profile at the anomalous top and tends to preserve an equivalent level of concentration laterally in the finest fraction; in the coarsest fraction, the maximum $\mathrm{Au}$ content is found in the upper horizon just above the mineralized structure; it is rapidly decreases laterally, in the surface halo [9].

The aim of this paper is to study: 1) the Au dispersion pattern in the weathering profile of the Mintom gold area (South Cameroon, Central Africa) and 2) the evolution of trace-element contents characterizing the bedrock, from the saprolite to the surface horizon.

\section{Geographical and Geological Setting}

Mintom is located in the southern part of Cameroon (Central Africa) between latitude $2^{\circ} 30^{\prime}$ and $2^{\circ} 45^{\prime} \mathrm{N}$ and longitude $13^{\circ} 15^{\prime}$ and $13^{\circ} 30^{\prime} \mathrm{E}$, within a humid equatorial climatic zone (Figure 1). The southern part of Cameroon is a vast area stretching from the Atlantic coast in the west to the Congo basin in the east. This area is constituted with plateaus which have lower altitude of $620 \mathrm{~m}$ [10]. The interfluves are asymmetrical with convex and convexo-concave hillsides joined to narrow or either more or less deep valleys. The area is covered by low altitude Atlantic forest vegetation [11]. The geological survey of the area is found in the Ntem complex (Figure 2a) which constitutes the cratonic basement of the southern Cameroon. It is known to represent the north western part of the vast Congo Craton in Central Africa [12,13]. This complex is limited to the north by a major thrust that marks the contact with the Pan-African orogenic belt [13, 14] (Yaounde group) and to the west by the Paleoproterozoic Nyong unit [15]. Chemical and geochronological data confirm its late Archean age $[15,16]$. This complex is also characterized by a granulitic complex distinguishes the Ntem unit, Nyong and Ayina units which were reactivated during the Eburnean orogeny [17], and sedimentary formation of Neo-proterozoic age (the Dja series). The bedrocks of the study area are comprised of discordant fine- to coarse-grained schists, dark gneissic series consisting of fine-grained gneisses with biotite and amphibole, dark grey migmatites which have been intruded by alkaline leucogranite with textures ranging from fine- to coarse-grained, dark basic gabbros and dark grey charnockitic rocks of the Ntem complex. The gold is located inside quartz veins within the quartzitic rocks. These quartz veins are related to the extension fractures whose are conformed to the schistosity (Figure 2b).

\section{Materials and Methods}

A pit was bored at the down slope of the interfluve from the surface into the saprolite $(150 \mathrm{~cm}$ depth) in the central part of the mineralized quartz veins at Zom (Figure 3). In the field, the detailed macroscopic relationships and structures were studied in situ for each horizon of the weathering profile and color using Munsell color chart.

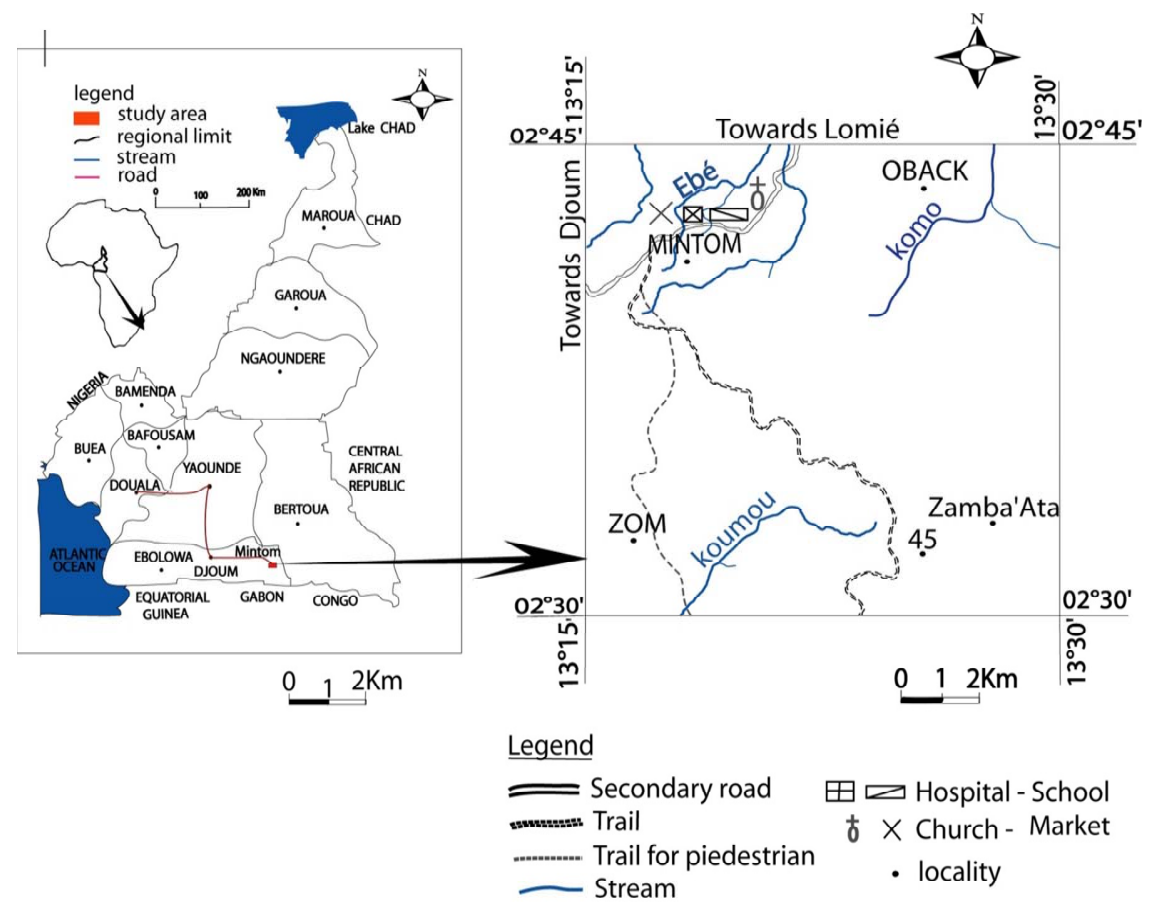

Figure 1. Location of study area. 


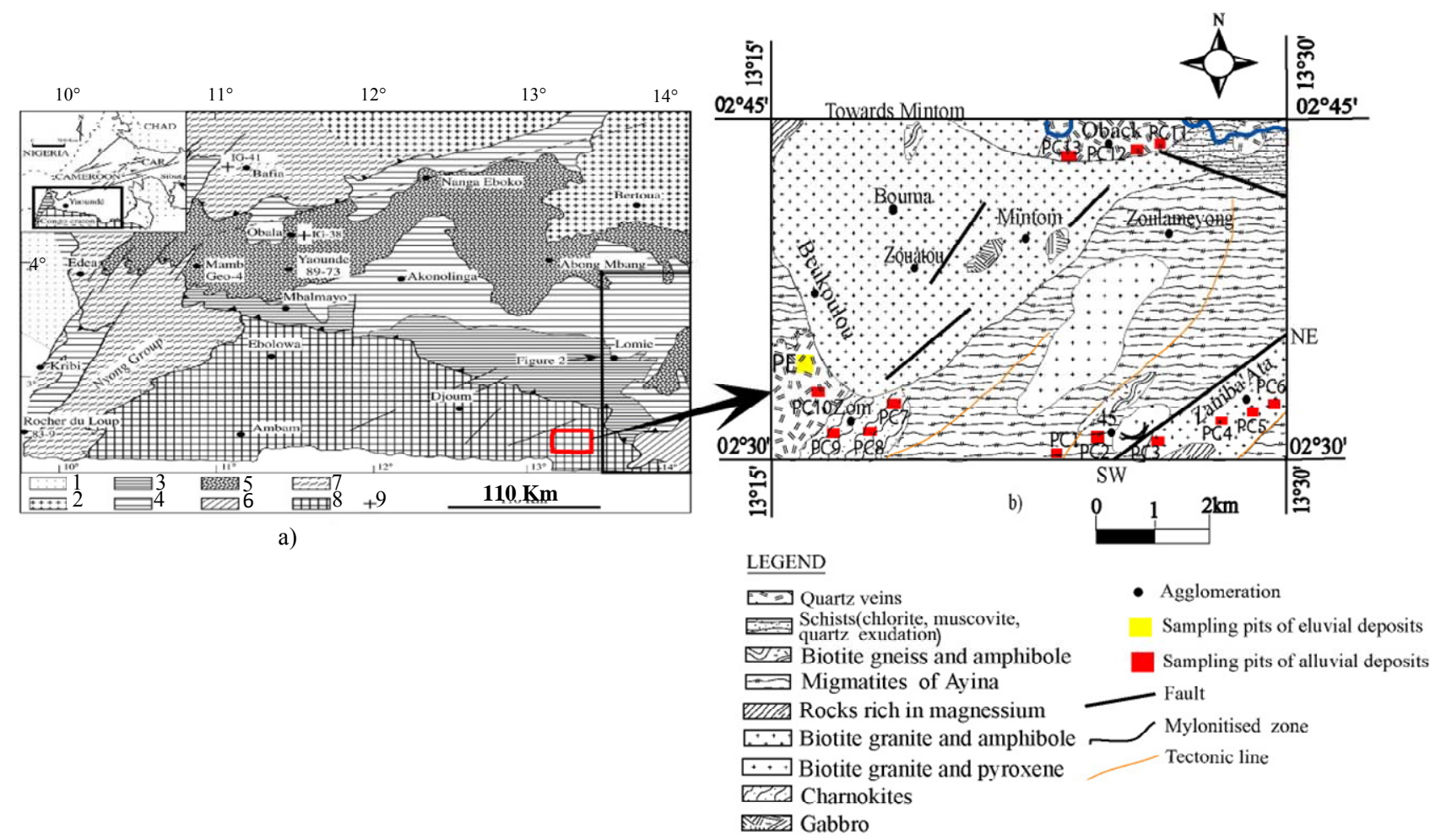

Figure 2. a) Geological sketch map of the southern Cameroon. 1-Coastal Cenozoic basin, 2-Pan-African granitoids of Yaoundé Group, 3-Low-grade schists, 4-Medium-grade schists, 5-High-grade gneisses and granulites, 6-Schisto-doleritic complex, 7-High-grade Paleoproterozoic or assumed gneisses Nyong and Bafia Group, 8-Archean Congo craton [14], 9-Sample location. b) Geological sketch map of the study area [25].

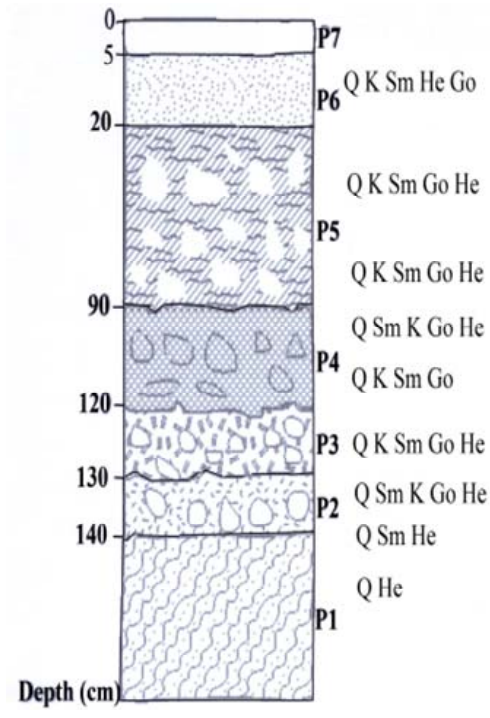

(a)

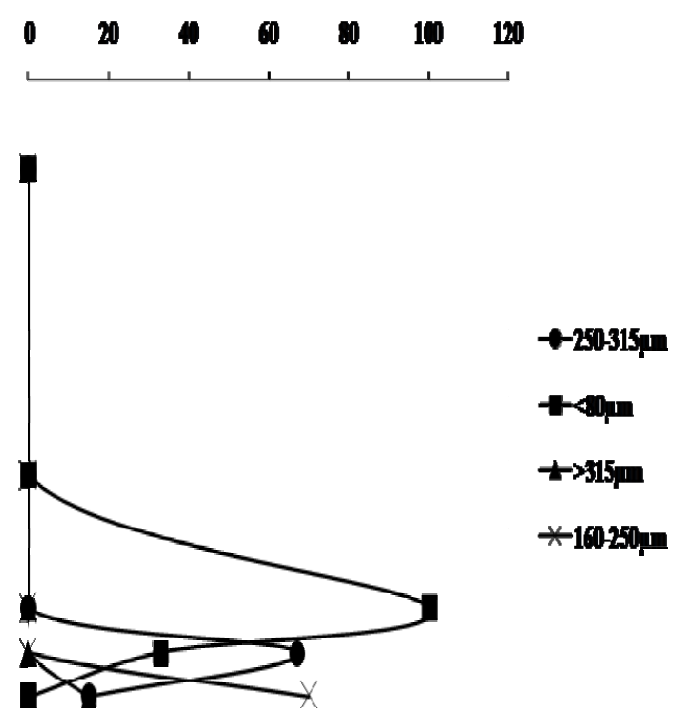

(b)

Figure 3. (a) The weathering profile of Mintom. P1-Parent rock, P2-Saprolite, P3-Spotted horizon, P4-Gravel horizon, P5-Nodular horizon, P6-Sandy-clayey horizon, P7-Humerous horizon; Q-Quartz, K-Kaolinite, Sm-Smectite, Go-Goethite, He-Hematite. (b) Percentages of gold grain sizes in weathered materials.

Two samples collected $(81$ per sample $=10 \mathrm{~kg})$ from the weathering profile for each horizon were carefully washed by means of a California pan. The samples were dried at $60^{\circ} \mathrm{C}$ and sieved to separate the following $\mathrm{Au}$ grain size fractions: minus 63 microns, $63-80$ microns, $80-160$ microns, 160 - 250 microns, 250 - 315 microns, 315 $500 \mu \mathrm{m}$ and above 500 microns.

At the same time, $3 \mathrm{~kg}$ samples were taken from each 
horizon for the mineralogical and chemical analyses which were carried out in the Australian Laboratory Services Minerals in Omac (Ireland). The mineralogical composition was determined by XRD of the powder bulk samples for each horizon. The resulting diffraction spectra were compared with a computerized data base of common minerals, whose automatic mineral-matching function was assisted by operator identification of phases consistent with the known compositions of the materials. Phase proportions were estimated by the peak matching program without calibration to synthetic mixtures of known phase proportions. Semi-quantitative analysis was performed [18]. Chemical analyses of major elements were done by Inductively Couped Plasma-Atomic Emission Spectrometry (ICP-AES) after dissolution through acid digestion procedure with $\mathrm{HF}, \mathrm{HNO}_{3}$, and $\mathrm{HClO}_{4}$. Chemical analyses of Rare earth elements, trace elements and base metals were determined by Inductively Coupled Plasma-Mass Spectrometry (ICP-MS). Powders were treated in a mixture of $\mathrm{HCl}$ and $\mathrm{HClO}_{4}$ acids at $120^{\circ} \mathrm{C}$ in sealed Teflon containers with dilute $\mathrm{HNO}_{3}$ acid dried. The residue was redissolved in an acid mixture $(\mathrm{HCl}$ and $\mathrm{HClO}_{4}$ ) and evaporated to dryness a second time before being redissolved in a mixture of three acids $\left(\mathrm{HF}, \mathrm{HNO}_{3}\right.$, and $\mathrm{HCl}$ ) at $100^{\circ} \mathrm{C}$. Sample solutions were analyzed in a Perkin Elmer Elan 9000 ICP-MS instrument. All the fractions were analyzed for $\mathrm{Au}$ by Inductively Couped Plasma-Atomic Emission Spectrometry (ICP-AES). The samples were dissolved completely in a strong acid mixture $\left(\mathrm{HC} 1, \mathrm{HNO}_{3}, \mathrm{HF}\right)$ and $\mathrm{Au}$ was extracted from the acid phase into an organic solvent. The detection limit for this method is $0.001 \mathrm{ppm}$.

\section{Results}

\subsection{The Weathering Profile}

The profile (Figure 3 ) presents from bottom to the top:

1) The parent rock (P1) is a whitish quartz vein that outcrops form large bands along the valleys. It's constituted of centimetric to millimetric minerals rich in quartz $(98.2 \%)$ and opaque minerals like iron oxide (1.8\%);

2) The coarse saprolite (P2), $10 \mathrm{~cm}$ thick, is made up of angular quartz fragments or blocks ( $60 \%$ by weight) embedded in a grey brown (5YR8/4) sandy-clayey matrix (which represents $40 \%$ by weight) and became redbrown (5YR2/2) on the top. The lower saprolite is mainly consisted of quartz $(89.1 \%)$, smectite $(9.7 \%)$ and minor amounts of hematite $(2.2 \%)$; when the upper saprolite is made up of quartz $(34.6 \%)$, smectite $(27.3 \%)$, kaolinite (25.2\%), goethite $(8.9 \%)$ and hematite $(4.0 \%)$;

3) The spotted clayey horizon (P3), $20 \mathrm{~cm}$ thick has angular quartz fragments or blocks embedded in a red (5YR6/4) silty-clay matrix with white and yellow spots and patches. The quartz block become less abundant and are of centimetric sizes. Quartz (30.3\%), kaolinite (26.3\%) and smectite $(25.3 \%)$ are the main minerals of the horizon; goethite $(10.5 \%)$ and hematite $(7.4 \%)$ are less abundant;

4) The gravel horizon (P4), $30 \mathrm{~cm}$ thick, is made up of centimetric angular quartz ( $50 \%$ of the total weight) embedded in red (5YR6/4) and red-brown (5YR2/2) clayey matrix. Quartz (36.4\%), kaolinite (39.3\%), smectite $(15.2 \%)$, and goethite $(9.1 \%)$ are the main minerals at the bottom of the horizon. At the top of the horizon, gravel grain sizes progressively decrease. Quartz (38.9\%), smectite $(35.8 \%)$, kaolinite $(27.4 \%)$, goethite $(10.5 \%)$, and hematite $(8.4 \%)$ are the main minerals;

5) The nodular horizon, $70 \mathrm{~cm}$ thick, consists on the top of the red (5YR6/4) sandy-clayey matrix (25\% of the total weight) rich in scattered nodules and quartz pebbles, and red-brown sandy-clayey matrix rich in centimetric sized quartz blocks at the base. Quartz $(31.1 \%-43.5 \%)$, kaolinite $(23.2 \%-35.6 \%)$, and smectite $(24.4 \%-26.1 \%)$ are the main minerals of the horizon; goethite $(4.3 \%$ $6.7 \%)$ and hematite $(2.2 \%-2.8 \%)$ are less abundant. At the base of this horizon, iron nodules form centimetric plates with layered textures whereas at the top, it has numerous centimetric and millimetric rounded ferruginous nodules. These nodules have a massive texture and sometimes a thin peripheral cortex; their grain sizes progressively decrease on the top of the horizon;

6) The sandy-clayey horizon, $15 \mathrm{~cm}$ thick, is composed of a yellow-brown (5YR5/6) clay-sandy matrix with rare rounded ferruginous nodules at the base. At the contact with the nodular horizon, the matrix comprises $90 \%$ of the total weight and the sizes of iron nodules rapidly decrease on the top of the horizon from 10 to 2 $\mathrm{mm}$ in diameter. Quartz (30.7\%), kaolinite (29.3\%), and smectite $(28.0 \%)$ are the main minerals; hematite $(9.3 \%)$ and goethite $(2.7 \%)$ are less abundant. The sandy-clayey horizon is covered by a light brown humic horizon, $5 \mathrm{~cm}$ thick, with indications of strong biologic activity.

\subsection{Geochemistry}

Table 1 presents the mean contents of some major and trace elements by horizon. The sampled weathered horizons are generally more aluminous and ferruginous, with high $\mathrm{P}_{2} \mathrm{O}_{5}$ than the parent rock (quartz veins), which is more siliceous than the weathered horizons. However, the nodular horizon is more ferruginous than the other weathered horizons of the profile with the exception of the top of the coarse saprolite which is more ferruginous and less siliceous (respectively $49.8 \% \mathrm{Fe}_{2} \mathrm{O}_{3}$ and $37.9 \%$ $\mathrm{SiO}_{2}$; Table 1). Also, values of trace elements like $\mathrm{Ba}$, $\mathrm{Co}, \mathrm{Ni}, \mathrm{Cu}, \mathrm{Zn}$, and $\mathrm{Sc}$ are relatively high in saprolite and surface horizon, and $\mathrm{Cr}$ and $\mathrm{V}$ are very high in nodular horizon. 
Table 1. Mean contents, by horizon in the pit of some oxides and trace elements (in \% for the 5 first ones, in ppm for the other ones).

\begin{tabular}{|c|c|c|c|c|c|c|c|c|c|c|c|c|c|c|c|c|}
\hline & & & $\mathrm{SiO}_{2}$ & $\mathrm{Al}_{2} \mathrm{O}_{3}$ & $\mathrm{Fe}_{2} \mathrm{O}_{3}$ & $\mathrm{~K}_{2} \mathrm{O}$ & $\mathrm{P}_{2} \mathrm{O}_{5}$ & $\mathrm{Ba}$ & $\mathrm{Cr}$ & V & Co & $\mathrm{Ni}$ & $\mathrm{Cu}$ & $\mathrm{Zn}$ & $\mathrm{Sc}$ & Th \\
\hline & & DL & 0.01 & 0.01 & 0.01 & 0.01 & 0.01 & 0.5 & 10 & 5 & 0.5 & 1 & 1 & 2 & 1 & 0.05 \\
\hline P6 & 0.2 & EA9 & 55.2 & 16 & 14.75 & 0.05 & 0.11 & 30 & 810 & 391 & 8 & 28 & 57 & 24 & 31 & 8.08 \\
\hline \multirow{2}{*}{ P5 } & 0.45 & EA8 & 44.3 & 13.9 & 28.1 & 0.03 & 0.14 & 20.7 & 2160 & 579 & 11 & 62 & 136 & 56 & 61 & 8.95 \\
\hline & 0.9 & EA7 & 44.5 & 14.5 & 26.4 & 0.05 & 0.13 & 37.7 & 1640 & 620 & 17 & 56 & 115 & 50 & 50 & 9.28 \\
\hline \multirow{2}{*}{ P4 } & 1.05 & EA6 & 70.7 & 9.98 & 7.7 & 0.03 & 0.05 & 26.9 & 320 & 229 & 4 & 21 & 46 & 12 & 21 & 4.2 \\
\hline & 1.2 & EA5 & 61 & 15.05 & 13.6 & 0.04 & 0.08 & 33 & 690 & 376 & 6 & 18 & 51 & 14 & 29 & 7.34 \\
\hline P3 & 1.3 & EA4 & 78.8 & 7.34 & 3.97 & 0.03 & 0.02 & 26.8 & 160 & 121 & 3 & 14 & 24 & 7 & 15 & 2.41 \\
\hline \multirow{2}{*}{$\mathrm{P} 2$} & 1.35 & EA3 & 37.9 & 2.32 & 49.8 & 0.03 & 0.72 & 90.4 & 530 & 415 & 29 & 181 & 343 & 239 & 44 & 0.69 \\
\hline & 1.4 & EA2 & 90.6 & 0.98 & 7.93 & $<0.01$ & 0.1 & 39.1 & 320 & 83 & 17 & 50 & 84 & 46 & 13 & 0.16 \\
\hline P1 & & EA1 & 97.4 & 0.42 & 0.64 & $<0.01$ & $<0.01$ & 10.7 & 250 & 12 & 1.4 & 5 & 7 & 6 & 2 & $<0.05$ \\
\hline
\end{tabular}

DL: Detection limit.

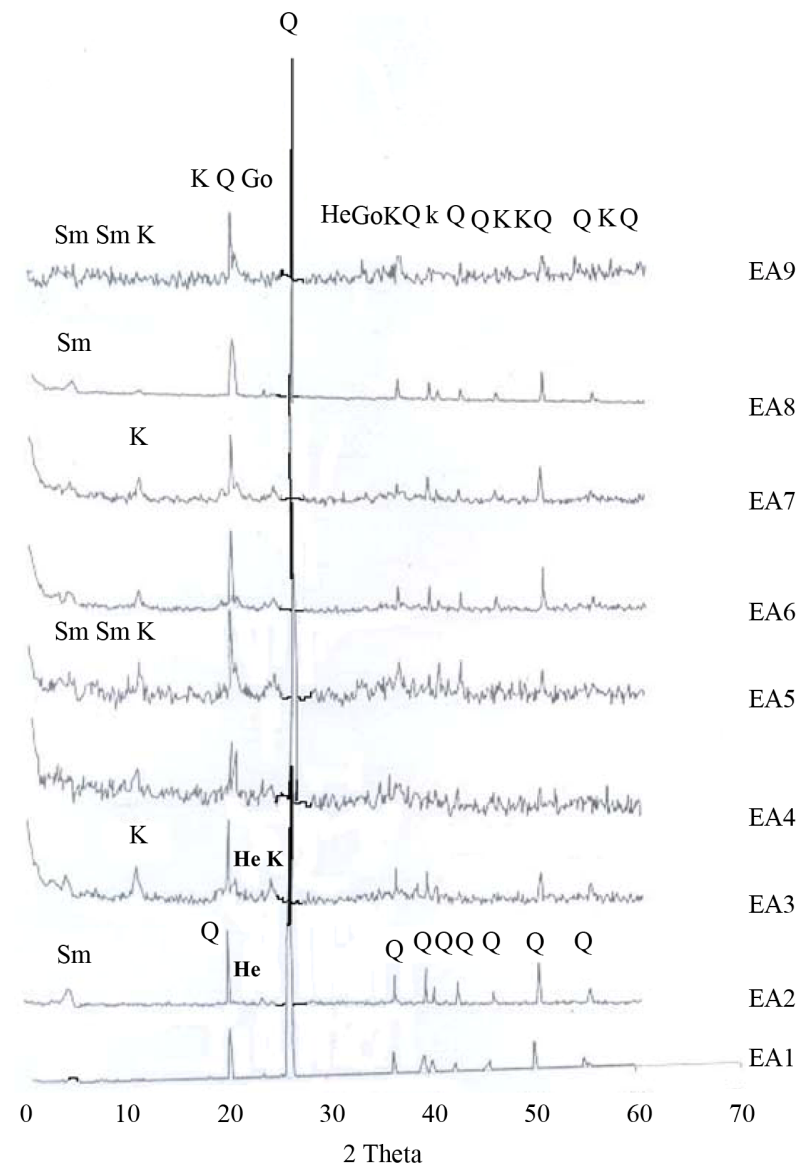

Figure 4. Diffractograms of the Mintom weathering profile samples. EA1-Parent rock, EA2-Lower saprolite, EA3-Upper saprolite, EA4-Spotted horizon, EA5-Lower gravel horizon, EA6-Upper gravel horizon, EA7-Lower nodular horizon, EA8-Upper nodular horizon, EA9-Sandy-clayey horizon; Q-Quartz, K-Kaolinite, Sm-Smectite, Go-Goethite, He-Hematite.

Thus, in the pit, the chemical characteristics of the inherited bedrock are not reflected in the five main horizons and the variation between horizons is vertically im- portant. In fact, trace elements concentrations shown increase from the bedrock to the saprolite, decrease in spotted and gravel horizons, highly increase in nodular horizon and decrease in surface horizon. The fact that points are scattered along $\mathrm{Cr}$ and $\mathrm{Ni}$ (Figure 5a), $\mathrm{Cr}$ and Co (Figure 5b) and $\mathrm{Al}_{2} \mathrm{O}_{3}$ and $\mathrm{Fe}_{2} \mathrm{O}_{3}$ (Figure 5c) binary diagrams is an indication that all weathered products are not from the parent rock (quartz vein) despite the good correlations between $\mathrm{Co}$ and $\mathrm{Ni}, \mathrm{Cu}$ and $\mathrm{Zn}, \mathrm{Ni}$ and $\mathrm{Cu}$ or $\mathrm{Zn}, \mathrm{Cu}$ and $\mathrm{Zn}$ (Figure 6). Gold has negative or feeble correlations with the other trace elements.

The REE concentrations normalized to quartz vein display patterns not similar to chondrite [19], and are parallel to sub-parallel (Figures 7(a) and (b)). The weathered horizons generally have low $\sum$ REE, with high LREE concentrations more than HREE relatively linked to the nature of the parent rock (Table 2). The sums of REE concentrations are widely variable and are high more than the quartz veined (33.12 - 154.8 ppm for weathered products against $10.88 \mathrm{ppm}$ for quartz vein). The REE concentrations normalized to quartz vein are mainly homogenous. However, quartz vein is more fractionated to chondrite with high $(\mathrm{La} / \mathrm{Yb})_{\mathrm{N}}$ ratio $(11.15)$, and prominent negative $\mathrm{Ce}$ anomaly (0.32) and little negative $\mathrm{Eu}$ anomaly (0.87); in contrast the weathered horizons have less fractionated to chondrite with low $(\mathrm{La} / \mathrm{Yb})_{\mathrm{N}}$ ratios (0.34 - 1.06), exception of spotted and surface horizons (7.24 and 1.53 respectively) and have high positive $\mathrm{Ce}$ anomalies (1.16 - 2.04), exception of the lower saprolite which has slightly negative Ce anomaly (0.78) and little or no Eu anomalies [20]. Moreover, the weathered horizons normalized to quartz vein present high $\mathrm{Ce}$ anomalies $(2.21$ - 6.11) with slightly positive or negative $\mathrm{Eu}$ anomalies and show that weathering is developed in the oxidizing environment [20].

The chemical signature of weathering profile is not vertically preserved. This tendency is strong for major elements and for the trace elements shown (Figures 5a- 

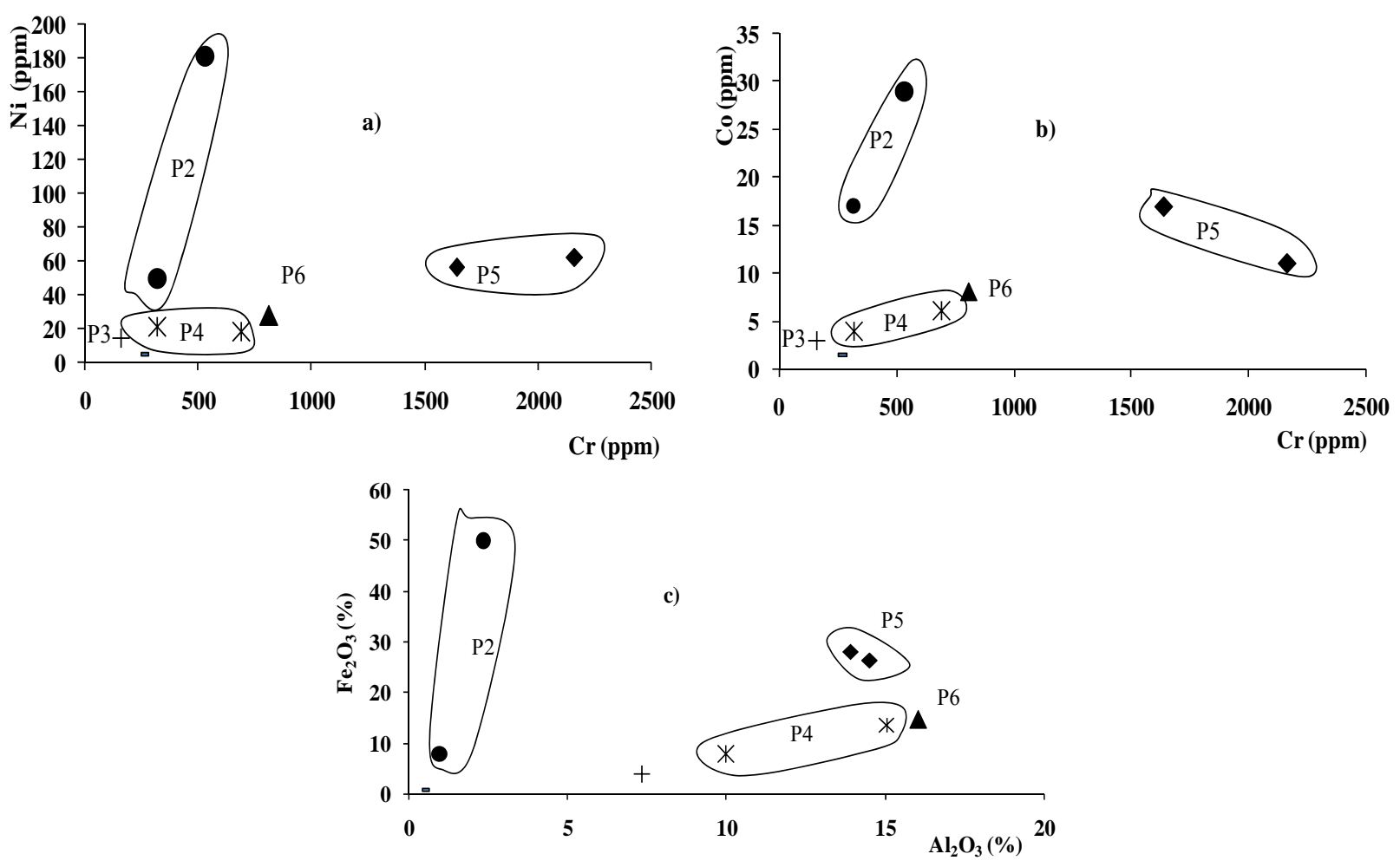

Figure 5. Scattergrams of some element contents of the weathered materials according to horizons P2, P3, P4, P5, and P6.

\begin{tabular}{|c|c|c|c|c|c|c|c|c|c|c|}
\hline $\mathrm{Pb}$ & 1 & & & & & & & & & \\
\hline $\mathrm{V}$ & 0.25 & 1 & & & & & & & & \\
\hline $\mathrm{Cr}$ & 0.8 & 0.41 & 1 & & & & & & & \\
\hline Co & -0.01 & -0.15 & 0.14 & 1 & & & & & & \\
\hline $\mathrm{Ni}$ & -0.18 & -0.02 & 0.09 & 0.92 & 1 & & & & & \\
\hline $\mathrm{Cu}$ & -0.12 & 0.01 & 0.16 & 0.9 & 1 & 1 & & & & \\
\hline $\mathrm{Zn}$ & -0.24 & -0.03 & 0.02 & 0.9 & 1 & 0.99 & 1 & & & \\
\hline $\mathrm{Zr}$ & 0.53 & 0.45 & 0.34 & -0.62 & -0.59 & -0.54 & -0.58 & 1 & & \\
\hline Th & 0.87 & 0.4 & 0.77 & -0.33 & -0.36 & -0.29 & -0.4 & 0.83 & 1 & \\
\hline \multirow[t]{2}{*}{$\mathrm{Au}$} & 0.09 & -0.1 & -0.08 & -0.27 & -0.26 & -0.22 & -0.22 & 0.29 & 0.23 & 1 \\
\hline & $\mathrm{Pb}$ & $\mathrm{V}$ & $\mathrm{Cr}$ & Co & $\mathrm{Ni}$ & $\mathrm{Cu}$ & $\mathrm{Zn}$ & $\mathrm{Zr}$ & Th & $\mathrm{Au}$ \\
\hline
\end{tabular}

Figure 6. Correlation diagram of gold with some trace elements of the weathered materials.
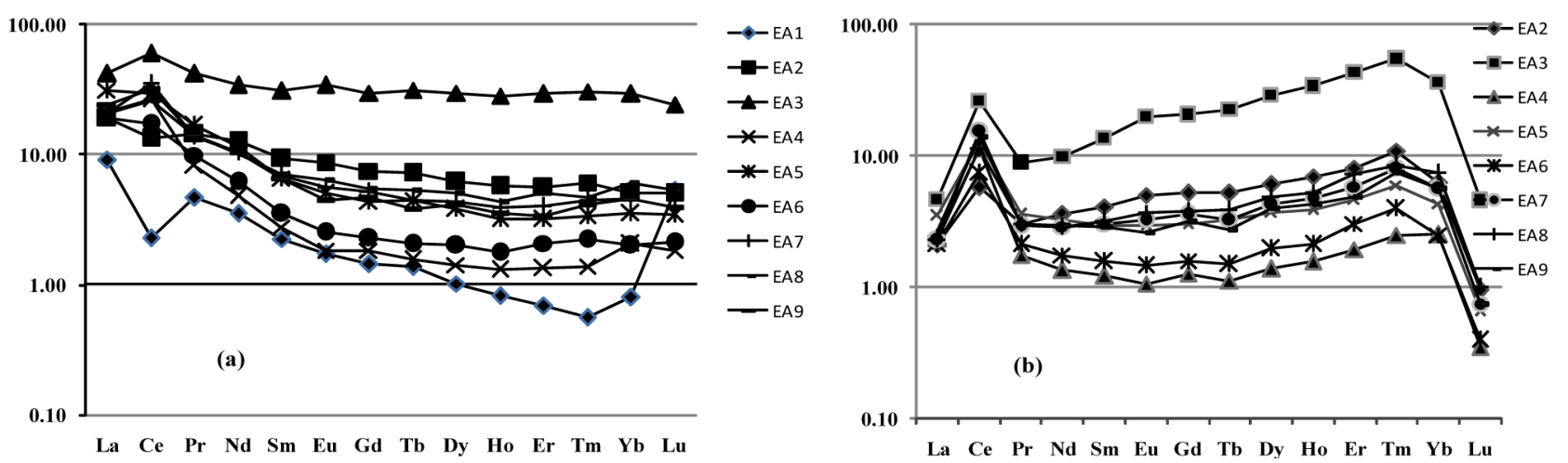

Figure 7. (a) Chondrite normalized REE patterns [36] and quartz normalized REE patterns of the weathered materials of Mintom area. 
Table 2. Rare Earth Elements (REE) concentrations in ppm of the weathered materials.

\begin{tabular}{|c|c|c|c|c|c|c|c|c|c|c|}
\hline & \multirow[b]{2}{*}{$\mathrm{DL}$} & \multirow{2}{*}{$\begin{array}{c}\text { P1 } \\
\text { EA1 }\end{array}$} & \multicolumn{2}{|c|}{ P2 } & \multirow{2}{*}{$\begin{array}{c}\text { P3 } \\
\text { EA4 }\end{array}$} & \multicolumn{2}{|c|}{$\mathrm{P} 4$} & \multicolumn{2}{|c|}{ P5 } & \multirow{2}{*}{$\begin{array}{c}\text { P6 } \\
\text { EA9 }\end{array}$} \\
\hline & & & EA2 & EA3 & & EA5 & EA6 & EA7 & EA8 & \\
\hline Depth (m) & & & 1.4 & 1.35 & 1.3 & 1.2 & 1.05 & 0.9 & 0.45 & 0.2 \\
\hline $\mathrm{La}$ & 0.5 & 3.3 & 7 & 15.4 & 7.8 & 11.5 & 7 & 7.6 & 7.6 & 8.8 \\
\hline $\mathrm{Ce}$ & 0.5 & 2.2 & 12.7 & 57.8 & 25.2 & 28.4 & 16.4 & 33.7 & 25 & 30.6 \\
\hline $\operatorname{Pr}$ & 0.03 & 0.64 & 1.96 & 5.71 & 1.13 & 2.29 & 1.36 & 1.9 & 1.95 & 1.93 \\
\hline $\mathrm{Nd}$ & 0.1 & 2.5 & 9 & 24.5 & 3.4 & 8.1 & 4.4 & 7.3 & 7.2 & 7.4 \\
\hline $\mathrm{Sm}$ & 0.03 & 0.52 & 2.15 & 7.09 & 0.64 & 1.52 & 0.82 & 1.59 & 1.64 & 1.51 \\
\hline $\mathrm{Eu}$ & 0.03 & 0.15 & 0.76 & 2.97 & 0.16 & 0.44 & 0.22 & 0.49 & 0.56 & 0.39 \\
\hline $\mathrm{Gd}$ & 0.05 & 0.44 & 2.3 & 9.13 & 0.56 & 1.34 & 0.7 & 1.57 & 1.66 & 1.42 \\
\hline $\mathrm{Tb}$ & 0.01 & 0.08 & 0.42 & 1.82 & 0.09 & 0.26 & 0.12 & 0.26 & 0.31 & 0.22 \\
\hline Dy & 0.05 & 0.39 & 2.37 & 11.35 & 0.54 & 1.45 & 0.77 & 1.67 & 1.91 & 1.56 \\
\hline Ho & 0.01 & 0.07 & 0.49 & 2.4 & 0.11 & 0.27 & 0.15 & 0.33 & 0.37 & 0.3 \\
\hline $\mathrm{Er}$ & 0.03 & 0.17 & 1.38 & 7.32 & 0.33 & 0.79 & 0.52 & 1 & 1.25 & 0.84 \\
\hline $\mathrm{Tm}$ & 0.01 & 0.02 & 0.22 & 1.1 & 0.05 & 0.12 & 0.08 & 0.16 & 0.17 & 0.15 \\
\hline $\mathrm{Yb}$ & 0.03 & 0.2 & 1.25 & 7.29 & 0.51 & 0.87 & 0.5 & 1.13 & 1.49 & 1.13 \\
\hline $\mathrm{Lu}$ & 0.01 & 0.2 & 0.19 & 0.92 & 0.07 & 0.13 & 0.08 & 0.15 & 0.2 & 0.15 \\
\hline$\sum \mathrm{REE}$ & - & 10.88 & 42.19 & 154.8 & 40.59 & 57.48 & 33.12 & 58.85 & 51.31 & 56.4 \\
\hline LREE & - & 9.75 & 35.87 & 122.6 & 38.89 & 53.59 & 30.9 & 54.15 & 45.61 & 52.05 \\
\hline HREE & - & 1.13 & 6.32 & 32.2 & 1.7 & 3.89 & 2.22 & 4.7 & 5.7 & 4.35 \\
\hline $\mathrm{a}$ & - & 8.63 & 5.68 & 3.81 & 22.88 & 13.78 & 13.92 & 11.52 & 8 & 11.97 \\
\hline$\left[\mathrm{Ce} / \mathrm{Ce}^{*}\right] 1$ & - & - & 2.21 & 4.12 & 5.64 & 3.79 & 3.73 & 6.11 & 4.55 & 5.03 \\
\hline$\left[\mathrm{Ce} / \mathrm{Ce}^{*}\right] 2$ & - & 0.32 & - & - & - & - & - & - & - & - \\
\hline$\left[\mathrm{Eu} / \mathrm{Eu}^{*}\right] 1$ & - & - & 1.12 & 1.18 & 0.89 & 0.97 & 0.95 & 1.04 & 1.09 & 0.91 \\
\hline$\left[\mathrm{Eu} / \mathrm{Eu}^{*}\right] 2$ & - & 0.88 & - & - & - & - & - & - & - & - \\
\hline $\mathrm{b}$ & - & - & 0.34 & 0.38 & 7.24 & 0.86 & 1.06 & 0.48 & 0.76 & 1.53 \\
\hline $\mathrm{c}$ & - & 11.15 & - & - & - & - & - & - & - & - \\
\hline
\end{tabular}

DL: Detection limit; $\mathrm{a}=\sum \mathrm{LREE} / \sum \mathrm{HREE} ; \mathrm{b}=(\mathrm{La} / \mathrm{Yb}) \mathrm{N}=($ Lasoil sample/La $) /($ Ybsoil sample/Ybquartz vein $) . \mathrm{c}=(\mathrm{La} / \mathrm{Yb}) \mathrm{N}=(\mathrm{Laquartz}$ vein $/ \mathrm{Lachondrite}) /$ (Ybquartz vein/Ybchondrite). [Ce/Ce*]1 $=($ Cesoil sample/Cequartz vein $) /\left[(\text { Lasoil sample/Laquartz vein })^{1 / 2}(\mathrm{Ndsoil} \mathrm{sample/Ndquartz} \text { vein })^{1 / 2}\right]$. $[$ Ce/Ce* $2=$ (Cequartz vein/Cechondrite)/[(Laquartz vein/Lachondrite $\left.)^{1 / 2}(\text { Ndquartz vein/Ndchondrite })^{1 / 2}\right]$. [Eu/Eu* $] 1=($ Eusoil sample/Euquartz veing)/[(Smsoil sample/ Smgquartz vein $\left.)^{1 / 2}(\text { Tbsoil sample/Tbquartzvein })^{1 / 2}\right]$. [Eu/Eu* $]^{2}=($ Euquartz vein/Euchondrite $) /\left[(\text { Smquartz vein } / \text { Smchondrite })^{1 / 2}(\text { Tbquartz vein/Tbchondrite })^{1 / 2}\right]$.

c). In fact, the geochemical study of the weathered products shows that each geological unit has a specific chemical signature: the quartz vein trend is characterized by high $\mathrm{SiO}_{2}$ and little REE, relatively charnokite/granite trend is characterized by $\mathrm{SiO}_{2}, \mathrm{~K}_{2} \mathrm{O}$ plus $\mathrm{CaO}$, and $\mathrm{MgO}$ contents, and a basic trend is characterized by the $\mathrm{Cr}, \mathrm{V}$ and $\mathrm{Ni}$ contents, probably reflecting the gabbro.

In relation to those data and to rock fragments found in the saprolite of the pit, we can say that:

- all weathered products are not reflecting the inherited bedrock chemical signature up to the surface;

- saprolite, spotted and gravel horizons are from quartz veins with high fragments of quartz and $\mathrm{SiO}_{2}$ contents, and are formed in situ, while nodular and surface horizons are from a basic rock like gabbro.

\subsection{Gold Grain Size in the Weathering Profile}

Initially, seven grain-size fractions have been chosen but only four fractions were isolated because of their low abundance or absence levels. The number of Au grains present in each fraction of the sample can be calculated and thus their percentages in relation to the total gold content (Table 3):

1) in the saprolite (P2), the number of $\mathrm{Au}$ grains is high more than the other horizons and the proportions of the coarse fractions ( $>315$ microns) are low (15\%); there is a significant medium fractions $(85 \%$ of $160-315 \mathrm{mi}-$ crons) and no fine fractions;

2 ) in the spotted clayey horizon (P3), the number of $\mathrm{Au}$ grains is decreased than the lower horizon and proportions of the medium fractions are the highest $(67 \%$ of 160 - 315 microns); fine fractions are low (33\% of $<80$ microns) and there is no coarse fractions;

3 ) in the gravel horizon (P4), the number of the $\mathrm{Au}$ grains is the lowest and fine material is prevalent $(100 \%)$;

4 ) in the nodular (P5) and surface horizons (P6), there is no visible gold fractions.

In the weathering profile, the total $\mathrm{Au}$ contents decrease from the saprolite to the gravel horizon, and visible gold disappears in the nodular and surface horizons; thus it seems that the coarsest fraction is enriched in the upper unit just above the quartz vein. However, gold chemical concentrations show inversely tendency with total $\mathrm{Au}$ contents not reflecting the visible gold behavior (Table 3). Au concentrations increase from the saprolite 
Table 3. Percentages of the total amount of gold of the different size fractions and total Au content in ppm ("total”) of each horizon.

\begin{tabular}{cccccccc}
\hline Horizons & Depth $(\mathrm{m})$ & Number of grains & $<80 \mu \mathrm{m}$ & $160-250 \mu \mathrm{m}$ & $250-315 \mu \mathrm{m}$ & $>315 \mu \mathrm{m}$ & Total \\
\hline P6 & 0.2 & 0 & 0 & 0 & 0 & 0 & 0 \\
P5 & 0.9 & 0 & 0 & 0 & 0 & 0 & 0.007 \\
P4 & 1.2 & 3 & 100 & 0 & 67 & 0 & 0.398 \\
P3 & 1.3 & 9 & 33 & 0 & 15 & 0 & 15 \\
P2 & 1.4 & 36 & 0 & 70 & & 0.008 \\
\hline
\end{tabular}

to the gravel horizon.

The study confirms that gold is accumulated in the horizons just above the mineralized quartz veins.

\section{Discussion}

The study of supergene distribution of metal patterns in tropical weathering profile has to integrate a series of complex processes, recent or former, making it difficult to understand [9]; and the behavior of various elements terrains is usual to refer to the general lateritic weathering model composed of three main units [5]. Moreover, in the Mintom area, the presence of five main units is made it more difficult to understand.

However, the close structural and chemical filiations between the different units and components of a lateritic weathering profile model in dry climate zones, in tropical rainforest, and more particularly in Central Africa were described in detail [20,21], such examples are fortunately known in Cameroon [20-22].

\subsection{Superficial Transfer of the Parental Chemical Signature}

In the Mintom area, weathering profile shows that saprolite and relatively spotted and gravel horizons clearly include inherited remnants of the primary materials (quartz vein). Moreover, the direct relationship to bedrock can be interpreted in terms of chemical analyses of the whole material. For weathering profile developed from a quartz vein, each of the five horizons has a specific chemical composition not depending for all the units on the bedrock chemical spectrum. It is verified in the nodular and surface horizons (P5 and P6). In these horizons, high $\mathrm{Cr}$ contents are not reflecting the bedrock chemical signature. The parental spectrum can still be recognized until the gravel horizon, particularly using trace elements. Indeed, when an element has a low content in the bedrock, it tends to increase in the saprolite and decreases in the spotted and gravel horizons; then, it tends to increase in the nodular horizon and slightly decreases in the surface horizon (Table 1).

\subsection{Gold Behavior in the Weathering Profile}

In the pit, visible gold accumulates vertically at the base of profile in relation to the quartz vein $\mathrm{Au}$ contents and disappears in the nodular and surface horizons. Indeed, primary gold dispersion is clearly evident from the parent rock up to the gravel horizon. Taking into account the number of grains variation between horizons (Table 3), gold is about 4 and 12 times more concentrated in the saprolite (P2) than in the spotted (P3) and gravel (P4) horizons respectively. Also, gold grain size shows that from the saprolite to the gravel horizon, coarse fraction decreases and there are no Au particles greater than 80 microns at the gravel horizon as well as the density variation follows the same tendency. It seems clear that this accumulation in the pit is linked to the concentration of the coarse fraction in the saprolite in relation to the primary mineralization content. However, this accumulation is not quite isovolumetric, as one cubic meter of the saprolite represents the weathering product of several cubic meters of the parent rock $[23,24]$, and after a complex polycyclic weathering process.

Gold shows some differences in comparison with the others trace-elements behavior studied here; indeed, there is no evident correlation between gold with another trace element. Conversely to the grain size evolution, its concentration increases from the saprolite up to the gravel horizon and decrease in the surface horizons. It seems indicate that high $\mathrm{Au}$ contents in the gravel horizon linked to both concentrations in matrix and quartz fragments.

\section{Conclusions}

The weathering profile of the Mintom gold area in south Cameroon is characterized by five main horizons:

1) a sandy-clayey horizon (P6) covered by a light brown humic horizon,

3) a lateritic nodular horizon (P5),

4) a gravel horizon (P4),

5) a spotted horizon (P3),

6) and the saprolite (P2).

The specific geochemical signatures of the bedrock along the whole profile are not preserved, particularly for the trace elements.

For gold, the geochemical anomaly is situated above the mineralized quartz vein in the weathered materials at the base of profile with high concentration in gravel ho- 
rizon. Conversely, visible gold is high in saprolite and the evolution of the Au dispersion is not the same in the different size fractions of the weathered materials:

- in the minus 80 microns size fraction, the Au content is only regular in spotted and gravel horizons;

- in the medium size fractions (160 - 315 microns), the $\mathrm{Au}$ is in high content and greatly decreases from saprolite up to the spotted horizon and disappears in the gravel horizon;

- in the plus 315 microns size fraction, the Au content only exists in saprolite and is absent in other weathered materials.

We can thus assume that the coarse-grained and finegrained gold situated at the base of profile is developed from the primary mineralization of quartz vein along the tectonic structures.

\section{Acknowledgements}

The authors are grateful to the staff of the Australian Laboratory Services Minerals in Omac, Ireland for chemical analysis and MIPROMALO for mineralogical analysis.

\section{REFERENCES}

[1] A. W. Mann, "Mobility of Gold and Silver in Lateritic Weathering Profiles, Some Observations from Western Australia," Economic Geology, Vol. 79, No. 1, 1984, pp. 38-49. http://dx.doi.org/10.2113/gsecongeo.79.1.38

[2] J. G. Webster and A. W. Mann, "The Influence of Climate, Geomorphology and Primary Geology on the Supergene Migration of Gold and Silver," Journal of Geochemical Exploration, Vol. 22, No. 1-3, 1984, pp. 21-42. http://dx.doi.org/10.1016/0375-6742(84)90004-9

[3] F. Colin and P. Vieillard, "Behavior of Gold in the Lateritic Equatorial Environment: Weathering and Surface Dispersion of Residual Gold Grains, at Dondo Mobi, Gabon," Applied Geochemistry, Vol. 6, No. 3, 1991, pp. 279-290. http://dx.doi.org/10.1016/0883-2927(91)90005-A

[4] S. M. B. de Oliveira and E. G. Campos, "Gold-Bearing Iron Duricrust in Central Brazil," Journal of Geochemical Exploration, Vol. 41, No. 3, 1991, pp. 233-244. http://dx.doi.org/10.1016/0375-6742(91)90005-F

[5] G. Bocquier, J. P. Müller and B. Boulange, "Les Laterites. Connaissances et Perspectives Actuelles sur les Mécanismes de Leur Differenciation," In: Livre Jubilaire du Cinquantenaire, A.F.E.S., Paris, 1984, pp. 123-138.

[6] C. Granier, P. Lajoinie and C. Vitali, “Géochimie de L'or et du Cuivre Dans les Formations Latéritiques Argileuses du Mont Flotouo (Ity, CBte d'Ivoire)," Bulletin de la Société Française de Mineralogie et de Cristallographie, Vol. 86, 1963, pp. 252-258.

[7] J. S. Toom's, "Exploration for Gold in the Humid Tropics," International Geochemical Exploration Symposium, Toronto, 2-6 March 1962, p. 90.

[8] R. Davy and M. El-Ansary, "Geochemical Patterns in the
Laterite Profile at Boddington Gold Deposit, Western Australia," Journal of Geochemical Exploration, Vol. 26, No. 2, 1986, pp. 119-144. http://dx.doi.org/10.1016/0375-6742(86)90062-2

[9] P. Lecomte and F. Colin, "Gold Dispersion in a Tropical Rainforest Weathering Profile at Dondo Mobi, Gabon," Journal of Geochemical Exploration, Vol. 34, 1989, pp. 285-301.

http://dx.doi.org/10.1016/0375-6742(89)90118-0

[10] E. Ekomane, "Etudes Sédimentologiques et Paléoenvironnementales des Roches Carbonates et Pélitiques de la Formation de Mintom, Sud-Est Cameroun," Ph.D. Thesis, l'Université de Yaoundé I, p. 189.

[11] R. Letouzey, "Atlas du Cameroun, Phytogéographie Camerounaise," Imprimerie Nationale, Yaoundé, 1968, p. 84.

[12] B. Bessoles and R. Trompette, “Géologie de L'Afrique: La Chaine Panafricaine, Zone Mobile d'Afrique Central (Partie sud) et Zone Mobile Soudanaise," Mémoire du BRGM, Orléans, Vol. 92, 1980, p. 378.

[13] C. K. Shang, M. Satir, E. N. Nsifa, J. P. Liegeois, W. Siebel and H. Taubald, "Archean High-K Granitoids Produced by Remelting of the Earlier Tonalite-TrondhjemiteGranodiorite (TTG) in the Sangmelima Region of the Ntem Complex of the Congo Craton, Southern Cameroon," International Journal of Earth Sciences, Vol. 96, No. 5, 2007, pp. 817-840. http://dx.doi.org/10.1007/s00531-006-0141-3

[14] C. Lerouge, A. Cocherie, S. F. Toteu, J. P. Milesi, J. Penaye, R. Tchameni, N. E. Nsifa and C. M. Fanning, "SHRIMP U-Pb Zircon Dating for the Nyong Series, South West Cameroon," Journal of African Earth Sciences, Vol. 45, No. 4-5, 2006, pp. 413-427. http://dx.doi.org/10.1016/i.jafrearsci.2005.11.010

[15] R. Tchameni, "Géochimie et Geochronology des Formations de l'Archéen et du Paléoprotérozoïque du SudCameroun (Groupe du Ntem, Craton du Congo)," Thèse de l'Université d'Orléans, 1997, p. 356.

[16] M. Lasserre and D. J. Soba, "Age Liberien des Granodiorites et des Gneiss à Pyroxènes du Cameroun Meridional," Bulletin du BRGM (Deuxième série), France, section IV, No. 1, 1976, pp. 17-32.

[17] S. F. Toteu, W. R. Van Schmus, J. Penaye and J. B. Nyobe, "U-Pb and Sm-Nd Evidence for Eburnean and PanAfrican High-Grade Metamorphism in Cratonic Rocks of Southern Cameroon," Precambrian Research, Vol. 67, No. 3-4, 1994, pp. 321-347. http://dx.doi.org/10.1016/0301-9268(94)90014-0

[18] A. K. Charkravorty and D. K. Ghosh, "Kaolinite-Mullite Reaction Series: The Development and Significance of a Binary Aluminosilicate Phase," Journal of the American Ceramic Society, Vol. 74, No. 6, 1991, pp. 1401-1406. http://dx.doi.org/10.1111/j.1151-2916.1991.tb04119.x

[19] W. F. McDonough and S. Sun, "The Composition of Earth," Chemical geology, Vol. 120, No. 3-4, 1995, pp. 223-253. http://dx.doi.org/10.1016/0009-2541(94)00140-4

[20] J. J. Braun, M. Pagel, J. P. Muller, P. Bilong A. Michard and B. Guillet, "Cerium Anomalies in Lateritic Profiles," Geochimica et Cosmochimica Acta, Vol. 51, No. 3, 1990, 
pp. 597-605.

[21] J. P. Ambrosi and D. "Nahon, Petrological and Geochemical Differentiation of Lateritic Iron Crust Profiles," Chemical Geology, Vol. 57, No. 3-4, 1987, pp. 371-393. http://dx.doi.org/10.1016/0009-2541(86)90059-8

[22] P. D. Ndjigui, P. Bilong and D. Bitom, "Negative Cerium Anomalies in the Saprolite Zone of Serpentinite Lateritic Profiles in the Lomié Ultramafic Complex, South-East Cameroun," Journal of African Earth Sciences, Vol. 53, No. 1-2, 2009, pp. 59-69.

http://dx.doi.org/10.1016/j.jafrearsci.2008.09.002

[23] G. H. Brimhall and W. E. Dietrich, "Constitutive Mass
Balance Relations between Chemical Composition, Volume, Density, Porosity, and Strain in Metasomatic Hydrochemical Systems: Results on Weathering and Pedogenesis," Geochimica Cosmochimica Acta, Vol. 51, No. 3, 1987, pp. 561-581.

http://dx.doi.org/10.1016/0016-7037(87)90070-6

[24] P. Lecomte, "Stone Line Profiles: Importance in Geochemical Exploration," Journal of Geochemical Exploration, Vol. 30, No. 1-3, 1988, pp. 35-61. http://dx.doi.org/10.1016/0375-6742(88)90049-0

[25] J. Gazel and G. Gerard, "Notice Explicative sur la Feuille Batouri Est (1/500 000),” D.M.G. Yaoundé, 1954, p. 43. 